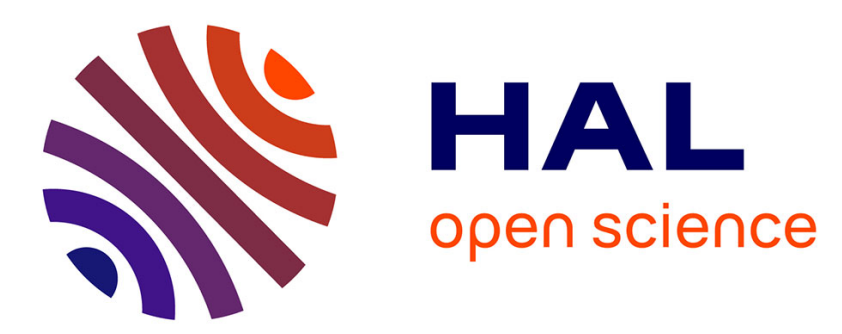

\title{
A Conceptual Model for Researching the Creation and Operation of Supply Networks
}

Christine Harland, Jurong Zheng, Thomas Johnsen, Richard Lamming

\section{To cite this version:}

Christine Harland, Jurong Zheng, Thomas Johnsen, Richard Lamming. A Conceptual Model for Researching the Creation and Operation of Supply Networks. British Journal of Management, 2004, 15 (1), pp.1-21. 10.1111/j.1467-8551.2004.t01-1-00397.x . hal-00858313

\section{HAL Id: hal-00858313}

\section{https://hal-audencia.archives-ouvertes.fr/hal-00858313}

Submitted on 5 Sep 2013

HAL is a multi-disciplinary open access archive for the deposit and dissemination of scientific research documents, whether they are published or not. The documents may come from teaching and research institutions in France or abroad, or from public or private research centers.
L'archive ouverte pluridisciplinaire HAL, est destinée au dépôt et à la diffusion de documents scientifiques de niveau recherche, publiés ou non, émanant des établissements d'enseignement et de recherche français ou étrangers, des laboratoires publics ou privés. 
Harland, C.M., Zheng, J., Johnsen. T. and Lamming. R.C. (forthcoming). A Conceptual Model for Researching the Creation and Operation of Supply Networks. Accepted for publication in the British Journal of Management, June 2003.

\section{A CONCEPTUAL MODEL FOR RESEARCHING THE CREATION AND OPERATION OF SUPPLY NETWORKS}

Christine Harland, Jurong Zheng, Thomas Johnsen and Richard Lamming, Centre for Research in Strategic Purchasing and Supply (CRiSPS), School of Management, University of Bath, Claverton Down, Bath, BA2 7AY, UK ${ }^{1}$

Corresponding author email : mnscmh@management.bath.ac.uk

\footnotetext{
${ }^{1}$ ProjectION is the Inter-Organisational Networking Project, which is undertaken by an alliance of the Universities of Bath, Cambridge and Brighton and sponsored by the EPSRC. The work of our research partners - Dr. Nick Oliver, Una McCormack, John Anderson and James Callaghan at the University of Cambridge and Prof. John Bessant and Dr George Tsekouras at the University of Brighton is gratefully acknowledged. The contribution of Marie Kenny as project administrator enabled the work to be carried out.
} 


\title{
A CONCEPTUAL MODEL FOR RESEARCHING THE CREATION AND OPERATION OF SUPPLY NETWORKS
}

\begin{abstract}
Research on supply networks has, to date, largely concentrated on describing single case studies of large, powerful companies and their influence over their networks. There has been relatively limited conceptual (or empirical) work on how these networks are created and operated. Researchers in ProjectION have developed, tested and applied a conceptual model to support the analysis of the networking processes involved in the creation and operation of inter-organisational networks of three main types - supply networks, innovation networks and learning networks. This paper presents the conceptual model for the creation and operation of supply networks.

Existing conceptual research relating to inter-organisational relationships and networks is reviewed in terms of its relevance to understanding supply networks; this research is drawn from the fields of strategic management, channel management, industrial marketing and purchasing, organisational behaviour and supply chain management. The different perspectives each field has on networks are highlighted. Contributions made by each in assisting to understand supply networks are discussed and synthesised. Findings from an exploratory survey are used to structure the design of a conceptual model for analysing the processes involved in the creation and operation of supply networks. The authors identify nine different types of networking activities and discuss the nature of these activities in the context of supply. Four different types of contextual factors relating to supply networks are identified. The model is tested in eight in-depth case studies and a validating survey of 58 focal firm networks. It is concluded that it provides a robust structure that enabled complex, cross-case analysis of multi-variable, multi-disciplinary data from inter-organisation product / service supply networks, but that further testing by other researchers is required.
\end{abstract}

\section{KEYWORDS}

Supply networks, Networking activities, Network context, Creation, Operation, Conceptual model

\section{INTRODUCTION}

In today's competitive, global, business environment, managers of primary activities are increasingly under pressure to improve performance of their product/service packages and reduce costs to compete internationally. Consequently, firms have sought to integrate individual operational functions, and externalise the focus of their management of operations beyond the firm boundary, upstream into their suppliers, into suppliers' suppliers, and downstream into their customers and customers' customers; here these extended webs of operational relationships are termed supply networks (Harland et al,1999).

Supply networks are nested within wider inter-organisation networks and consist of inter-connected entities whose primary purpose is the procurement, use and transformation of resources to provide packages of goods and services. Supply networks therefore essentially consist of a set of inter-connected supply chains, encompassing both upstream and downstream relationships. From an analytical point of view, the analyst, depending on the focus of investigation, can determine the boundary of a supply network. 
Harland, C.M., Zheng, J., Johnsen. T. and Lamming. R.C. (forthcoming). A Conceptual Model for Researching the Creation and Operation of Supply Networks. Accepted for publication in the British Journal of Management, June 2003.

For example, we could examine the total supply network for a firm that could be represented by the set of upstream and downstream organisations it deals with, either directly or indirectly, from original source of raw material or service creation, to ultimate end customer. This would provide a map of all relationships within that firm's supply network. This might be valuable if, for example, we were investigating network structure with a view to rationalising the total supply base. Alternatively, we could focus attention on a particular product and examine the product supply network containing only those actors contributing to the manufacture, distribution and sale of that product. We therefore need to identify a 'focus' for a supply network and the purpose of analysis to enable us to bound it.

More broadly, the concept of supply has been proposed and summarised as "an holistic approach to managing operations within collaborative inter-organisation networks, allowing the formulation and implementation of rational strategies for creating, stimulating, capturing and satisfying end customer demand through innovation of products, services, supply network structures and infrastructures, in a global, dynamic environment" (Harland et al, 1999). This concept represents and frames the convergent issues and interests relating to inter-organisational flows of resources, products and services within supply networks.

To date much of the research specifically examining supply networks has been observational and anecdotal, describing case examples of firms that appear to have managed their networks and achieved some form of competitive advantage. Benetton (Jarillo and Stevenson, 1991), Toyota (Womack et al, 1990), and Nissan (Nishiguchi, 1994) are examples of such accounts. The descriptive nature of these cases, however, presents a problem for managers as there is little evidence of critical analysis of the circumstances of these companies and the contexts of their networks; consequently little guidance has been provided as to how supply networks of different types facing different business situations can be created and operated effectively. Also the cases have been conducted in many and varied ways; there was no overall guiding conceptual model of how to investigate supply networks.

ProjectION aimed to research empirically a reasonable number and variety of supply networks in different sectors and business contexts to attempt to develop a taxonomy of supply networks and to provide managerial guidance on how to create and operate supply networks of different types in different circumstances. We wanted to use a robust and consistent conceptual model to ensure that cross-case comparison could be performed. In this paper we describe our search for such a model and, when an appropriate model was not found, our development of a conceptual model for examining the creation and operation of supply networks. The following section describes the methodology used to research available conceptual models, develop a model through exploratory research, ground it in literature and apply and test it empirically. 
Harland, C.M., Zheng, J., Johnsen. T. and Lamming. R.C. (forthcoming). A Conceptual Model for Researching the Creation and Operation of Supply Networks. Accepted for publication in the British Journal of Management, June 2003.

\section{METHODOLOGY}

This section describes the methodology for the creation and development of the conceptual model. A schematic for the methodology is shown in Figure 1.

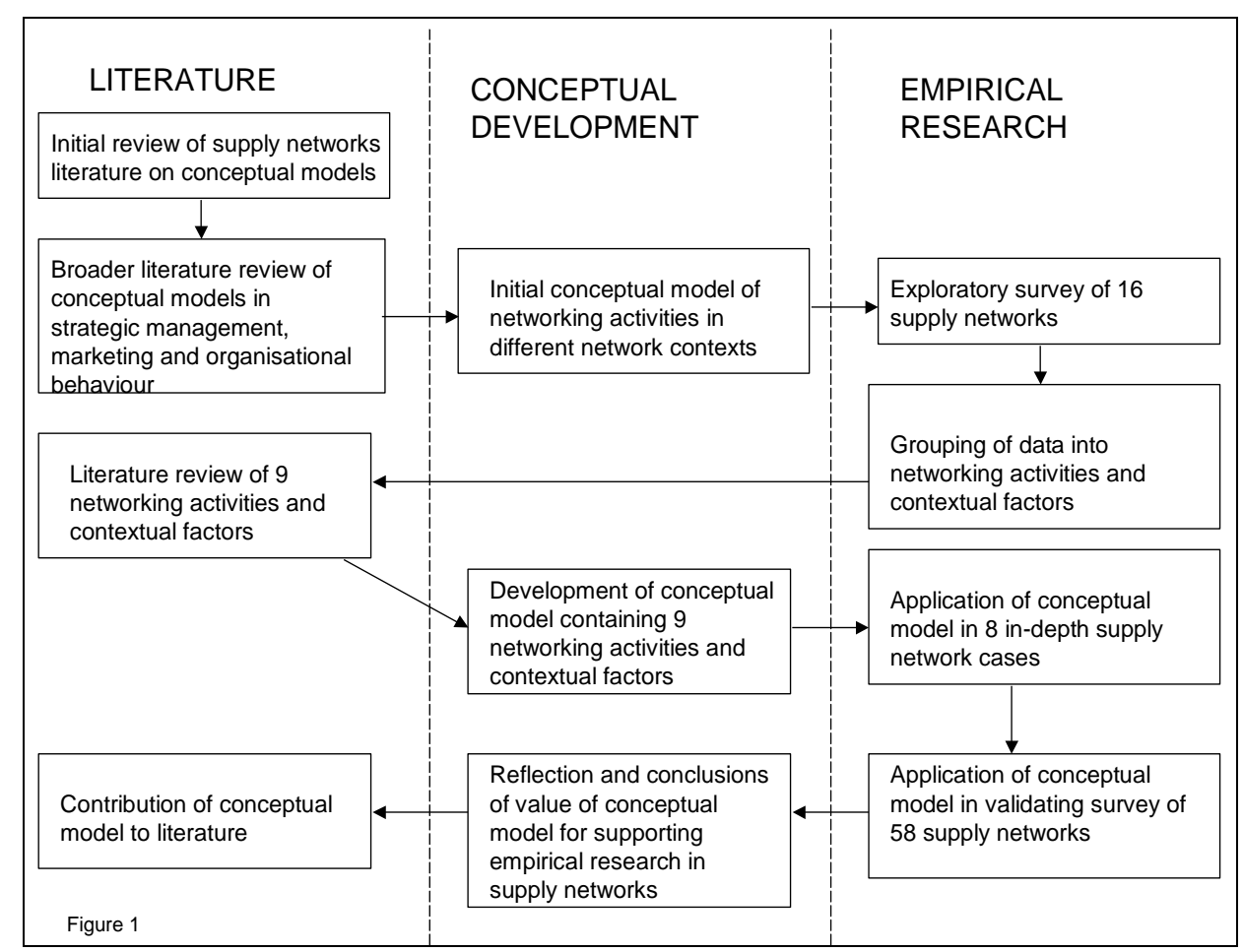

As researchers in supply networks coming from an operations management / purchasing and supply perspective, we initially searched our own literature area for any conceptual models that might provide a consistent and robust method for conducting the empirical studies of supply networks at the core of ProjectION. The first literature section of this paper provides this initial review of the supply network literature. Whilst some interesting analytical approaches were reviewed, there did not appear to be a strong conceptual model that would enable us to conduct the substantial empirical study we intended. The literature review was broadened, therefore, to embrace strategic management, marketing and organisation behaviour as studies of inter-organisational networks were being reported on in these fields. The second literature section presents the findings from this broader review.

Using ideas and elements of a range of authors work from the range of fields of research examined, we constructed an initial conceptual framework of networking activities occurring in different network contexts. This is described and presented in the section titled 'initial conceptual framework'. As a framework it was relatively hollow and to 'fill it in' we conducted an exploratory survey of 16 supply networks, described in the section titled 'exploratory survey'. This survey explored a large number of variables relating to networking and to the network context within which networking occurred. The data was grouped quite loosely initially according to whether it related to operations oriented observations, such as those concerned with materials planning and control, or to social aspects of networking, such as whether any social events were held between members of the supply network. The data within these initial groups were explored more deeply to look for patterns and sub-groupings. This exploratory research enabled the construction of an initial conceptual model containing a set of networking activities and contextual factors. 
At this stage we went back to the literature to ground this set of networking activities and contextual factors and develop our ideas on these further. As a result of this research of the literature, we refined the set of networking activities and contextual factors and developed the initial conceptual model further. The conceptual model was then used throughout ProjectION to provide consistency and structure to the empirical research. It was applied in 8 in-depth case studies, and in a subsequent validating survey of 58 supply networks. After the completion of ProjectION we reflected on the value of the conceptual model and sought to contribute to literature on this aspect of the research in addition to ProjectION's main findings arising from the empirical research.

The rest of this paper examines the main stages in the development of the conceptual model. Whilst the schematic and the discussion appear to imply a linear, staged process, in fact it was far more messy and iterative. Because the focus and excitement in ProjectION lay in the empirical research in international supply networks, it was only on completion of the work that the research team took the opportunity to reflect on this conceptual development.

\section{INITIAL SUPPLY NETWORKS LITERATURE REVIEW OF CONCEPTUAL MODELS}

This section reviews the conceptual models we examined in the supply networks literature.

\section{Supply chain management}

The supply chain management literature has provided models of flows within chains of supply (for example Stevens 1989, Houlihan, 1987, Jones and Riley, 1985, Christopher, 1992, Farmer and Ploos van Amstel, 1991). However, these have focused more on logistics flows (i.e. volume and timing of materials), transactions and short term supply decisions, than on strategic or structural aspects of supply networks. They have also focused on chains of supply, rather than networks thus only providing a partial picture of the process of supply, and disregarding the true complexity of supply networks. It is only relatively recently that supply networks have been conceptualised and analysed.

\section{Supply networks}

Harland (1996) provided a framework differentiating between four levels of analysis for considering supply - the internal supply chain, the dyadic relationship, the external supply chain and the supply network. Whilst useful in its application to categorising prior research, this framework presented a structural (and static) picture and gave no understanding of processes and activities occurring within networks.

De Toni and Nassimbeni (1995) did consider processes and activities within networks and, unlike the logistics based models, examined less tangible features of supply networks. They highlighted particular aspects of relationships that affected the ability of focal firms to plan the governance structure; these were the choice of the type of relationship with suppliers, the development and use of adequate procedures for the selection, evaluation and monitoring of the sources, the system of incentives, risk-sharing practices and rewards for suppliers, and tools to control any possible opportunistic tendencies. Furthermore, they found that the ability of a focal firm to plan the governance structure of supply relationships was closely related to the stability and effectiveness of the supply network in which it operated. This work highlighted the significance, 
Harland, C.M., Zheng, J., Johnsen. T. and Lamming. R.C. (forthcoming). A Conceptual Model for Researching the Creation and Operation of Supply Networks. Accepted for publication in the British Journal of Management, June 2003.

therefore, of the role of particular networking activities in achieving stable, effective networks.

Harland and Knight (2001) derived six network management roles from literature and empirical research in supply networks serving the healthcare sector. These were: network structuring agent, co-ordinator, advisor, information broker, relationship broker and innovation sponsor. They identified key team competence requirements associated with each role; however, no guidance was provided on which roles were more or less important in different types of supply networks in different circumstances. This research, therefore, helped to support research, through categorising different roles, but it did not support managers wishing to choose to play an appropriate role at a particular time in a particular context.

It appeared from this initial review, therefore, that conceptual models of supply networks were becoming more holistic and strategic, developing from their origins that had been based on relatively operational, tangible aspects of supply chains. However, no one conceptual model was evident that appeared to satisfy the requirements for research within ProjectION to support examination of a wide range of supply networks in different sectors, and to provide managerial guidance on how to network within these. Therefore the literature review was spread to cover other related fields of knowledge where studies of inter-organisation networks were being reported.

\section{BROADER LITERATURE REVIEW OF STRATEGIC MANAGEMENT, MARKETING AND ORGANISATIONAL BEHAVIOUR}

The criteria for wider investigation of the literature were based on identifying those areas that appeared relevant to the broader concept of supply and inter-organisational networks research. Relevant conceptual development was found in strategic management, marketing, industrial marketing and purchasing, and organisational behaviour.

\section{Strategic management and marketing networks research}

Many strategic management authors, notably Porter (1980, 1985, 1987), Johnston and Lawrence (1988) and Jarillo (1993) concerned themselves with strategic networks. Jarillo (1988) defined strategic networks as long term, purposeful arrangements among independent firms that allow them to gain or sustain competitive advantage vis-à-vis their competitors outside the network. Similarly, predominantly from a marketing perspective, Campbell and Wilson (1996) defined a value-creating network as a series of dyadic and triadic relationships that have been designed to generate customer value and build sustainable competitive advantage. Also, Porter's value system (1985) was effectively a (vertical) strategic network, being the sum of individual players' value chains. Porter highlighted the benefits of influencing the configuration of suppliers' value chains to optimise performance and of improving co-ordination between a firm and its suppliers' value chains or its channel value chains to lower cost, or enhance differentiation. This body of work, and the value-add based models within it, are largely underpinned by industrial economics theory, particularly transaction cost theory, that supports deliberate action of the firm to adjust the balance of activities conducted in- house or subcontracted, according to optimisation of transaction costs in the value system.

The potential for creation of a strategic network was recognised by Coase (1937), who identified a managerial choice of an alternative arrangement to either market or hierarchy. The potential for management of a strategic network was provided by Williamson (1975) who identified four reasons why transaction costs arise and are not optimal - bounded 
Harland, C.M., Zheng, J., Johnsen. T. and Lamming. R.C. (forthcoming). A Conceptual Model for Researching the Creation and Operation of Supply Networks. Accepted for publication in the British Journal of Management, June 2003.

rationality, the nature of future uncertainty in business, a limited supply of players for any transaction, and the tendency for firms to be opportunistic. The core focus of strategic management models for networks, therefore, was on deliberate exertion of power and influence to reduce transaction costs for the firm's benefit.

The strategic network models provide a managerial, normative, approach that helps to explain how large, powerful, focal firms such as Toyota (Womack et al, 1990, Fruin 1992), Nike (Lorenzoni and Baden-Fuller, 1995), Benetton (Jarillo and Stevenson, 1991), Corning (Lorenzoni and Baden-Fuller, 1995), Nissan (Nishiguchi, 1994), McDonald's (Jarillo, 1993), Volvo (Kinch, 1992) and Apple (Jarillo, 1993; Lorenzoni and Baden-Fuller, 1995) appear to have created and managed networks to their advantage. The industrial economic underpinning provides a useful theoretical explanation of why these powerful focal firms have behaved as reported. They have opportunistically exploited bilateral dependency, thereby manipulating the market and effectively reducing choice (Nooteboom, 1993).

Most of the discussion about strategic networks has occurred during the 1990s; there is still only a limited empirical base consisting of predominantly case study research. It is not clear whether these particular firms and their networks should be viewed as special cases. The majority of documented case studies of strategic networks relate to relatively high volume, low variety, manufacturing networks (if variety is considered at the level of the network and compared to all types of manufacturing or service networks). The contribution of strategic network research, therefore, could be viewed as being applicable to powerful focal firm networks exhibiting these types of characteristics, but as yet applicability to other network types is untested. There was little evidence of robust, guiding conceptual models that underpinned these case studies, so caution should be applied to any cross-case comparison across these authors' cases.

A different view of networks is apparent in a body of literature related to marketing. Early models of the channel environment include Achrol et al (1983) whose work was summarised as "a first step in ... identifying and dimensionalising the major variables influencing and ordering the structure". The model conceptualised different segments of the environment of channels, namely the input, output, competitive and regulatory environments, all contained within a larger macro environment. The channel, or for our purposes the downstream supply network, was shown to be influenced by particular factors within these environment segments; this highlighted the significance of considering the impact of contextual variables.

The Industrial Marketing and Purchasing (IMP) Group has provided models of industrial networks that focus on long-term mutually beneficial relationships and adaptation processes that occur within them. This group of researchers have developed concepts and language to understand the interaction process in dyadic relationships and the embeddedness of these in industrial networks; their Interaction Model characterised short-term episodes of exchange and longer-term features of a relationship between a customer and a supplier (Håkansson, 1982). This interaction was conceptualised as occurring within an atmosphere arising from the closeness, dependency, expectations and co-operation of the parties. The model positioned the exchange and party specific atmosphere as being contained in a larger environmental system. The interaction approach was developed to help provide understanding of continuous exchange relationships occurring between a limited number of identifiable actors (Håkansson and Snehota, 1989); it incorporated aspects of inter-organisational theory (Van de Ven et al, 
Harland, C.M., Zheng, J., Johnsen. T. and Lamming. R.C. (forthcoming). A Conceptual Model for Researching the Creation and Operation of Supply Networks. Accepted for publication in the British Journal of Management, June 2003.

1975) and the work of the new institutionalists from industrial economics (notably Williamson, 1975). However, in comparison with the latter the distinct focus has been on the factors that bond companies together, such as trust and commitment, rather than opportunism and power that tend to be at the centre of industrial economics theory.

Emphasising that no business is an island, the IMP group extended the focus from individual buyer-supplier relationships to industrial networks in their development of the Actors, Resources and Activities (ARA) model (Håkansson, 1987) which characterised links between activities, ties between resources and bonds between actors. Håkansson and Snehota (1995) further developed the broadening of interest to networks, extending the activity links in the ARA model to an activity pattern, the actor bonds to a web of actors and the resource ties to a resource constellation.

The ARA model of networks is useful to the study of supply networks, as is the conceptualisation of three different, though interwoven, networks. However, the model provides a relatively generic picture of networks primarily to help describe and explain the nature of continuous exchange relationships; it does not provide an operational understanding of the processes and activities that companies seeking to co-ordinate and manage networks can apply to leverage the potential value of the network (a process which we term 'networking'). A better understanding of networking has been provided by the organisational behaviour literature.

\section{Organisational behaviour research}

Our research objectives sought to gain an understanding of appropriate processes, tools and techniques for inter-organisational networking in different industrial and market situations. Ebers and Grandori (1997) identified two important questions related to inter-organisational co-ordination: - first, what configuration of flows of resources and information can be effectively governed and, second, what co-ordination mechanisms enable this governance? They identified the importance of third parties playing intermediary and mediating roles, delegation to central authorities and structure, institutionalisation of inter-firm systems of rules and procedures, and use of bilateral or multilateral systems of guarantee and safeguarding via incentives and resource commitment. Grandori and Soda (1995) and Grandori (1997) further specified the importance of communication, negotiation and decision making, incentive systems, selection systems, routines, rules and procedures, a liaison and integration role, group problem solving, planning, programming and information system and property rights sharing.

Snow et al (1992) also recognised the importance of third party mediating roles; they identified three broker roles: - the architect, the lead operator and the caretaker. The architect facilitates the building of specific networks and yet seldom has a clear understanding of all specific operating networks; the lead operator formally connects specific firms together into an ongoing network, and the caretaker focuses on activities that maintain and enhance the existing network. They emphasised that these three managerial roles are crucial to the success of any network.

These findings within the organisational behaviour literature were drawn on in the supply networks research by Harland and Knight (2001), cited above; this demonstrates the integration of these areas of knowledge. Also the recent work of Dyer and Nobeoka (2000) investigated the development of knowledge and knowledge sharing processes in key suppliers to Toyota, again highlighting the overlap of organisational behaviour and 
Harland, C.M., Zheng, J., Johnsen. T. and Lamming. R.C. (forthcoming). A Conceptual Model for Researching the Creation and Operation of Supply Networks. Accepted for publication in the British Journal of Management, June 2003.

supply networks fields of study. The organisational behaviour literature in this area, therefore, provides understanding of the processes of networking and the roles that players adopt within networks, though consideration of the strategic and structural contexts of networking receive less attention in this work i.e. it is not clear which networking processes are more or less appropriate for different network circumstances.

In summary, it appears that the strategic management and channel management models have taken a predominantly strategic and structural orientation, with a strong focus on power and opportunism, however, these models have provided little by way of guidance on networking activities and processes within networks. The industrial network models have provided useful understanding of interaction processes within dyadic relationships and the embeddedness of these in industrial networks, albeit these models have been largely descriptive; they have not provided any operational models of the processes and activities that companies who seek to co-ordinate and manage networks can apply to leverage the potential value of the network. This issue has been examined in more detail in the organisational behaviour literature, primarily in terms of the importance of co-ordination mechanisms; however, apart from the studies arguing the importance of various network broker roles, the focus in organisational behaviour studies has largely been on dyadic relationships rather than wider networks. Finally, supply chain research has provided useful frameworks of transformation processes; however, again the focus of the majority of the supply chain literature has been on chains as opposed to networks. Also, existing literature on supply networks tends to focus on the integration of logistical activities and resources; little attention has been paid to more behavioural aspects, such as how individual actors in supply networks resolve conflicts or make decisions. There was little evidence in any of the literature of understanding of different types of networks and contingent behaviour appropriate to different circumstances; this required an understanding of network context.

The findings from the initial literature review were used as the basis for development of an initial conceptual framework of networking activities in different network contexts.

\section{INITIAL CONCEPTUAL FRAMEWORK}

Some key principles were drawn from the literature review.

1. Taking an operations management perspective, supply network actors and resources can be considered 'inputs' to the process of 'operating a network'

2. Operating a network involves transforming resources into goods and services which are 'outputs' of the supply network

3. This operation of a supply network involves a range of tangible and less tangible activities

4. Supply networks operate in different network contexts

5. Networking activities should be appropriate to the network context

Using the basic operations management 'input-process-output' model of transformation of resources into goods and services (Slack et al, 1998), the boundary of analysis was stretched beyond an operation within a firm, to a supply network. The network context was added as an element of the framework. Using the ICAM (ICAM, 1981; Godwin et al, 1989) development of the input-process-output model to include consideration of 'mechanisms' or 'enablers' and 'constraints', an initial conceptual framework was constructed, as shown in Figure 2. 


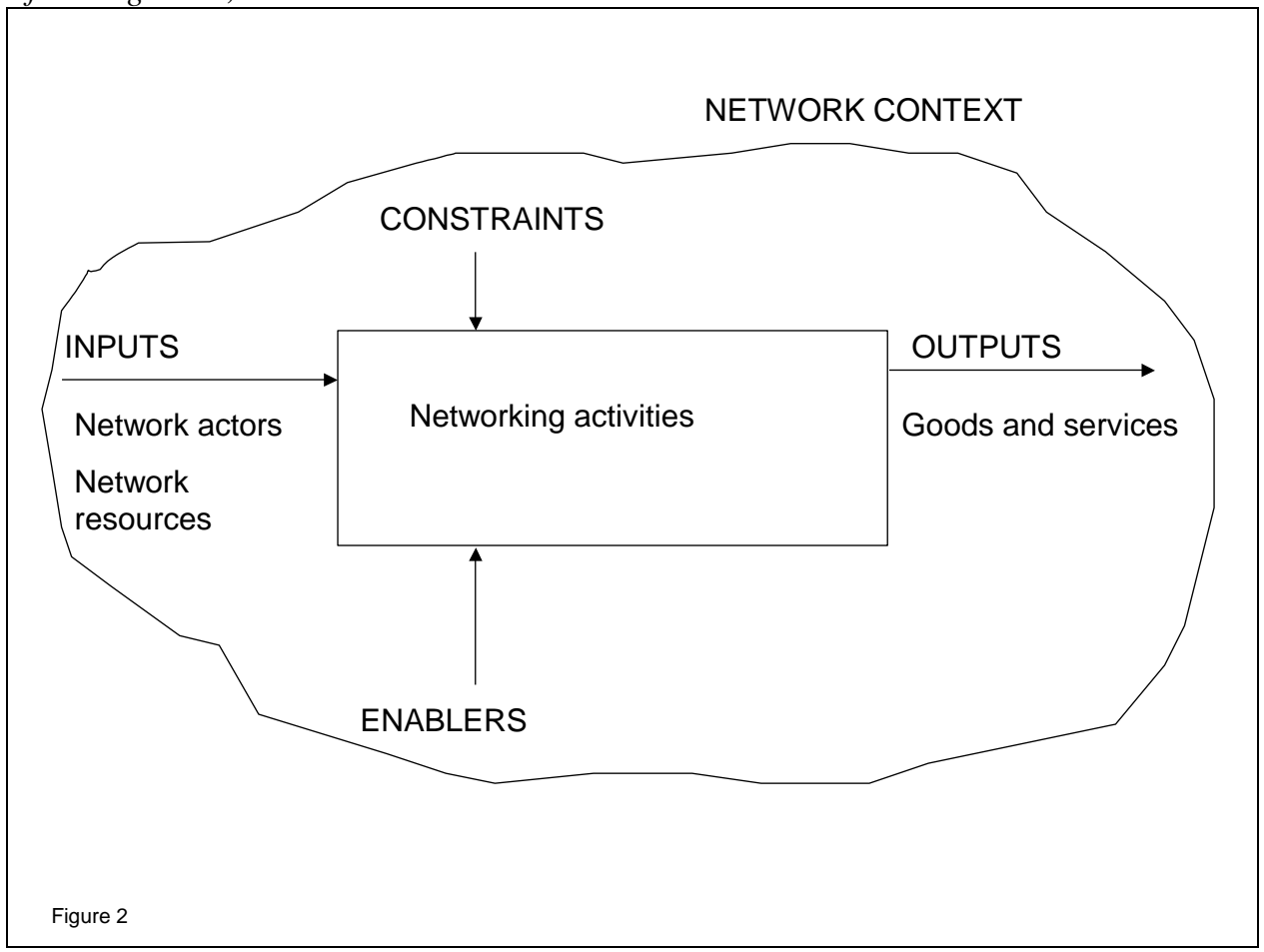

$<$ Insert figure 2 here >

The main elements of this initial conceptual framework were used to guide the structure and content of the exploratory survey. The next section discusses the methodology and findings of the exploratory survey.

\section{EXPLORATORY SURVEY OF SUPPLY NETWORKS Methodology for the exploratory survey}

A semi-structured interview was designed containing sections on inputs to supply networks, networking activities, outputs from the supply network, the supply network context, enablers and constraints of networking. Within these sections specific questions were not identified - it was intended to learn from the interviews about each of these elements in different types of supply network.

It was decided to conduct a relatively short exploratory study involving examination of specific product / service supply networks in different industry groups where the research team had a reasonable chance of gaining access; five groups were chosen - automotive, fast-moving consumer goods, electronics, pharmaceuticals and communications technology services. Access to 16 organisations in these groups was facilitated. The survey was conducted by at least two researchers performing semi-structured face-to-face interviews. The interviews were tape recorded and transcribed. The transcripts were analysed and coded to highlight initial groupings of data. Interviewing 16 organisations in five industry groups allowed us to explore how the operation of supply networks varied in different network contexts. This enabled us to examine how patterns of networking activities related to patterns of network contexts.

\section{Findings of the exploratory survey}

There is evidence to suggest that inter-organisation networks are generally long-term, evolving phenomena (Lundgren, 1995) involving long-term relationships between actors in the network. However, we were examining specific product / service supply networks nested within these inter-organisation networks. Therefore, as each product / service was designed and developed, a new product / service supply network was 'created' through 
Harland, C.M., Zheng, J., Johnsen. T. and Lamming. R.C. (forthcoming). A Conceptual Model for Researching the Creation and Operation of Supply Networks. Accepted for publication in the British Journal of Management, June 2003.

the sourcing decisions of which suppliers would be used for that specific product / service. Therefore, working with this unit of analysis it became apparent that it was appropriate to explore how the product / service supply network was created and as the product / service was manufactured and provided, how this network was operated. This led to the finding that the initial conceptual model should be modified to highlight supply network creation as a different process to supply network operation.

Some of the networking activities that occurred within the supply networks examined related to tangible inputs, transformation and outputs from the supply network. Interviewees were able to provide information in a fairly structured way on these activities, typically tracing the materials flow through the network. To help gain this information a supply network map was drawn of the different organisations involved from original raw material source through to ultimate supply of a product / service. This map was useful in drawing out other activities involving members of the supply network.

Some of the discussions examined how information flowed through the network and how it was processed; this tended to relate to tangible, operational information, such as drawings and specifications, purchase orders, delivery schedules and invoices. However, some discussions related to less tangible information and action, such as what happened in the supply network when a dispute between parties occurred and how this was resolved. Some observations were on social exchange; there was evidence of friendships within supply networks, or attempts to pull members of the network together through a meeting with a social side to it.

The observations were grouped over time under the following headings that represented clusters of related activities:

- partner selection

- resource integration

- information processing

- knowledge capture

- social co-ordination

- risk and benefit sharing

- decision making

- conflict resolution

- motivating

Of these, partner selection was only appropriate when product / service supply networks were being created or recreated; all the other factors related to both supply network creation and the operation of existing supply networks. The term 'partner selection' was used to represent the coming together of parties to a product / service supply relationship. Rather than 'supplier selection', partner selection takes into account that suppliers are part of the decision making process as they decide whether to bid for new product/ service supply business. In the larger inter-organisation network system, there may be an existing long-term relationship between supplier and buying organisation relating to other products and services i.e. the parties may already be partners in other product / service supply networks.

The exploratory survey also gave rise to an initial grouping of contextual factors that were discussed by participants in the survey; these were:-

- market environment

- product / service package 
Harland, C.M., Zheng, J., Johnsen. T. and Lamming. R.C. (forthcoming). A Conceptual Model for Researching the Creation and Operation of Supply Networks. Accepted for publication in the British Journal of Management, June 2003.

- operations process

- supply network structure

- focal firm supply network strategy

The exploratory survey findings provided some initial indications that there were some fundamental differences between sets of factors that appeared to influence creation and operation of supply networks in different network contexts i.e. different mixes of contextual factors relating to market environment, supply strategy, network structure, operations process and product / service packages appeared to relate to different sets of networking activities (Zheng et al, 1997; Lamming et al, 2000).

There was evidence arising form the exploratory survey that success of supply network creation and supply network operation was enabled by certain factors. For example, during new product development the use of technology to transfer drawings and specifications aided information processing, supporting the partner selection activity. Existing relationships in other product/ service supply networks enabled conflict resolution to be successful as both parties were inter-connected and committed to each other in these other networks. However, it emerged that it was difficult to distinguish between enabling and constraining factors. Whilst information technologies may have enabled some activities to be performed, they also constrained those activities; for example, electronic data interchange (EDI) enabled quicker exchange of order transaction data between supply network actors, but in itself it imposed constraints on the parties as they had to conform to a common standard of data specification and compatible information systems. Using the terms 'enablers' and 'constraints' helped provoke discussion in the interviews, so it was felt that they were useful elements of the conceptual model, even if classifying influencing factors into the two categories proved problematic.

Both sets of emergent networking activities and network context factors were investigated back in the literature. The next two sections explore research to date on each networking activity and the contextual variables.

\section{LITERATURE REVIEW OF NETWORKING ACTIVITIES}

In this section the networking activities indicated as being important in the exploratory survey are explored further through various literatures.

\section{Partner selection}

Partner selection was highlighted as being a central activity in the network creation process. The term was used to include not only selecting individual players to be involved in the value creation process of a particular product/service package, but also deciding on the strategy for the desired structure of the overall supply network i.e. whether a broad or a narrow supply network, through multi- or single sourcing, appeared more appropriate. The relative merits of broad and narrow networks have been examined in the marketing literature (Håkansson, 1982) as well as the purchasing and supply literature (Nishiguchi, 1994). Easton and Quayle (1990) investigated the advantages and disadvantages between single and multiple sourcing networks and suggested that single sourcing networks would be more rigid and stronger, because of the dense flow of exchanges between them. There may be disadvantages in a narrow network structure, such as increased risk, fewer contacts and therefore less knowledge sharing, and reduced ability to adapt to changes in the environment through switching (Sabel et al, 1987; Easton and Quayle, 1990). 
Harland, C.M., Zheng, J., Johnsen. T. and Lamming. R.C. (forthcoming). A Conceptual Model for Researching the Creation and Operation of Supply Networks. Accepted for publication in the British Journal of Management, June 2003.

Furthermore, companies may develop a portfolio of the different types of relationships they want, ranging from close strategic relationships to loose non-strategic relationships (companies often adopt their own terminology for this portfolio approach). Many classifications can be found in the literature; Cousins (2001) has suggested a typology based on two dimensions: - level of certainty and level of dependency. These result in four types of inter-firm relationships: - traditional/adversarial, tactical collaboration, opportunistic behaviour, and strategic collaboration.

The key issues relating to partner selection that exercised the survey participants were:

- which individual players to select

- how many players to involve in the value creation process of a particular product/service package

- what type of relationship to pursue with different types of players

The literature supported taking a broad view of the term 'partner selection' as in reality the process is likely to be interactive with two or more active parties rather than, as implied by the term 'partner selection', one active and one passive party (Ford et al, 1986).

\section{Resource integration}

Economists have long recognised that resource owners increase productivity through co-operative specialisation (see for example Alchian and Demsetz, 1972). Following a transaction cost economic logic, productivity gains are possible when firms are willing to make transaction-specific investments (Williamson, 1985). However, it is questionable whether this economic rationale sufficiently explains co-operation and indeed integration of resources between suppliers and buyers, as co-operation and integration are essentially viewed as so-called 'bilateral dependency' leading to lack of choice and increased risk of opportunism and thus a market failure. For this reason Dubois argues (1994), that transaction cost economics is insufficient in explaining networking between firms. Indeed, for example, Dyer's (1996) research of supplier networks in the automotive industry revealed that tightly integrated and spatially condensed production networks with high levels of co-specialised human resources outperformed more loosely integrated production networks with low levels of inter-firm specialisation. Human co-specialisation or integration may take the form of extensive human interaction or cross-transfer of staff. Based on Japanese experiences in supplier development, Hines (1996) discussed the wide use in Japan of both permanent and temporary exchanges of staff such as 'business group integration', 'employee release', and loaning of staff during periods of labour shortage. In a study of Marks and Spencer, Tse (1985) found that the retailer's technologists spend most of their time at the suppliers' plants, working closely with technical personnel (see also Lamming, 1996). This apparently improved co-operation with suppliers, as it allowed employees from one company to obtain a better understanding of the other. As shown by Clark and Fujimoto (1991), such co-operation may enable not only manufacturing process improvements, but also product development.

Integration may also involve physical resources, such as manufacturing equipment and technology. Suppliers are often required to invest in manufacturing equipment that is dedicated to a particular customer (asset specificity); customers may also finance the equipment themselves which is then used by and within the supplier's plant. In the retailing sector, for example, practices such as vendor-managed or co-managed inventory (VMI or CMI) enable suppliers to assess stock level data, via Electronic Data Interchange 
Harland, C.M., Zheng, J., Johnsen. T. and Lamming. R.C. (forthcoming). A Conceptual Model for Researching the Creation and Operation of Supply Networks. Accepted for publication in the British Journal of Management, June 2003.

(EDI), and take the necessary replenishment action (Scott-Morton, 1991; Lamming, 1996).

Finally, site specificity, or what we would term facility configuration, can be observed in many Japanese networks (for instance Toyota - see Dyer, 1996) again leading to a closer-knit network. The large body of literature on industrial clusters and regional networks is an example of the importance of this phenomenon (see, for example, Saxenian, 1991). At the micro level there are many examples of (particularly automotive) suppliers re-locating and adapting their facilities to large customers. Little research to date, however, has examined the significance of this type of activity across industries.

\section{Information processing}

It was highlighted in the exploratory survey that the exchange and processing of information between suppliers and buyers is critical to the creation and operation of successful supply networks. In supply chains information processing has been shown to be a key activity for managing the impact of the Forrester effect i.e. the phenomenon where real demand information from the end of the chain becomes distorted as it is interpreted, processed and passed up the supply chain (Forrester, 1961). Apart from exchange of demand information, exchange of more strategic information within supply networks, including strategy, market, technology, or new product information, may be important to ensure the long-term prosperity of the network.

With the advance of e-commerce and e-business, information and communications technologies are becoming powerful mechanisms for information processing. Modern process technologies, such as EDI (Christopher, 1992) and Internet-based, 'network technologies,' such as e-mail and Intranets, may have great potential for improving information exchange (see for example Scott-Morton, 1991). However, there is still little empirical research confirming the appropriate use of information technology in information processing in different types of supply networks. There were some indications in this survey that information technology is mostly used for exchange of routine information, and not always regarded as effective.

Efficient and mutual information exchange is also at the heart of the concept of lean supply (Lamming, 1993, 1996). Lamming's concept of cost transparency (Lamming, 1993; Lamming et al, 1996) is based on mutual exchange of cost information, as a step beyond the traditionally practised 'open-book negotiation' which most often implies that the supplier has to provide the buyer with all relevant cost data, but not vice versa. Hence, Lamming argues for the importance of mutual information exchange, which leads to closer co-operation and therefore more efficient supply.

\section{Knowledge capture}

The exchange, and more importantly capture, of knowledge (for example, process, technology, or market knowledge) may be seen as a separate activity, which focuses on innovation and the long-term competitiveness of the supply network as a whole.

'Organisational learning' has been recognised as an imperative since the early 1990s (Argyris and Schon, 1996). Also at the inter-organisational level, it is being increasingly recognised that innovation involves what Lundvall (1992) has termed 'collective entrepreneurship', a central element of which is learning i.e. giving rise to inter-organisational learning and innovation. Shared or collective learning, however, is not a new phenomenon; the basic rationale is that there is more to collective learning than 
Harland, C.M., Zheng, J., Johnsen. T. and Lamming. R.C. (forthcoming). A Conceptual Model for Researching the Creation and Operation of Supply Networks. Accepted for publication in the British Journal of Management, June 2003.

the sum of the learning of interacting components. ${ }^{2}$ There are thus strong indications in the literature that capturing knowledge is an important networking activity. This is also a central element of lean supply (Lamming, 1993), which emphasises the importance of manufacturers learning in concert with suppliers.

Recently, the interest in mechanisms for learning, such as 'learning networks', has highlighted the significance of the learning imperative to enable companies to raise their awareness and develop their skills in several fields (see for example Powell et al, 1996, and CIRIA/The Tavistock Institute, 1996). An example of such an inter-organisational learning arrangement is the Japanese practice of 'kyoryokukai' or supplier organisations (Hines, 1996).

\section{Social co-ordination}

Social interaction is recognised as enabling the development of good personal relationships; Nohria (1992) has argued that all organisations are in important respects social networks and this was also highlighted as being important at the inter-organisational level.

While supply networks may be seen as being more purposeful inter-firm arrangements than purely social networks (Brass and Burkhardt, 1992), they may still benefit from social interaction, because they, like any other form of network, consist of inter-personal relationships. Granovetter's concept of the strength of weak ties $(1973,1985)$ also indicates that strong resource connections in networks have to be complemented by a set of weak, often informal, ties, as these are likely to provide a conduit to important information. The link between social relationships and information has also been examined by Uzzi (1997) who proposed that socially embedded relationships have three important features: trust, fine-grained information transfer and joint problem-solving arrangements. In a similar vein Grandori and Soda (1995) discussed social co-ordination and control as a mechanism to obtain stable relationships based on group norms, reputation and peer control (see also Ouchi, 1979, 1980).

Social interaction is mostly ad hoc but it may potentially also be more deliberate thus taking the form of social co-ordination. Examples of what we would see as social co-ordination include team-building exercises, which are often used within organisations to develop and improve social bonds. Such activity across organisational boundaries, however, may be equally important although existing knowledge of the role and forms of this type of activity is limited.

\section{Risk and benefit sharing}

Several pieces of work have pointed to the importance of reaching a fair and balanced division of both risks and benefits derived from joint effort between alliance partners and also between buyers and suppliers (e.g. Sako, 1992; Womack et al, 1990; Grandori and Soda, 1995). This is generally related to the problem of securing sufficient levels of co-operation and commitment, whilst at the same time minimising damaging routines such as opportunistic behaviour.

The nature of risk and benefit sharing may vary according to the type of collaboration. In the case of joint ventures or strategic alliances, risks and benefits are often shared through joint ownership. In these kinds of relationships formal agreements such as obligation

\footnotetext{
${ }^{2}$ For instance Piore and Sabel (1984) provide several examples where significant externalities were generated by regional networks of firms, as early as the first days of the industrial revolution.
} 
Harland, C.M., Zheng, J., Johnsen. T. and Lamming. R.C. (forthcoming). A Conceptual Model for Researching the Creation and Operation of Supply Networks. Accepted for publication in the British Journal of Management, June 2003.

contracting, profit sharing schemes, property rights sharing, or ownership control, may provide important incentive systems for the parties to collaborate (Grandori and Soda, 1995).

Also in the context of supply networks, mutual risk and benefit sharing has been shown to be critical to achieve sustained customer-supplier collaboration. The work by Womack et al (1990) on the global automotive industry showed the significance of establishing a basic contract to ensure the long-term commitment of all parties during both product development and operation, and to allow sensitive information and knowledge to be exchanged. Their work uncovered how a vehicle assembler and its component suppliers engaged in a mutual process of establishing prices and analysing costs, enabling the two parties to jointly seek ways to cut costs and improve quality. Risk and benefit sharing may thus be related to different types of joint innovation, including product and process innovation and, in relation to the latter, also supply chain innovation (New and Burnes, 1998). This is a natural consequence of the high amount of risk involved in innovation which requires that suppliers make specific investments to a particular customer that are bound to include a certain level of uncertainty (Hines, 1996). Therefore, the establishment of a mutually agreed measurement system has been argued to play an important role in assessing and sharing the benefits gained from an alliance in an equitable manner (Stuart and McCutcheon, 1996). Despite the fact, however, that this is recognised as a central issue in the joint venture and strategic alliance literature, there is still a lack of rigorous cross-industry empirical research on risk and benefit sharing within supply networks.

\section{Decision making}

Decision making in networks refers to the process by which choices within the network are made. It can be a problem, due to the wide dispersal of information and/or lack of clear authority structure. Thus decision and negotiation mechanisms have been argued to be a key element of networking (Grandori and Soda, 1995). However, whereas this process has been the subject of many studies in organisational behaviour research (e.g. March, 1988) much less attention has been paid to this process in supply network research.

Decision making processes involve issues of combining objectives and information, resolving differences, and establishing routines, rules and procedures. Networks may evolve decision making mechanisms, some of which can incorporate routinized structures and processes. A level of sharing in the decision making process may be seen as a key element of networking in supply networks as a way of building and maintaining a set of mutual partnerships. Killing (1988) suggested that shared decision making and control may be positively influenced, in joint ventures and strategic alliances, by similar skills and equal contribution. However, again research on this aspect of decision making in supply networks is limited.

\section{Conflict resolution}

Conflicts often arise within single organisations between individuals due to differences in perspectives or expectations. As networks are likely to be even more diverse than integrated organisations the risk of conflict is potentially great. Inter-firm networks have the added problem that they are unlikely to have any formal authority structures or official lines of reporting; the use of hierarchy and authority mechanism have been found to resolve differences between actors in some forms of network (Grandori and Soda, 1995), though their incidence is not common. Not surprisingly one of the characteristics 
Harland, C.M., Zheng, J., Johnsen. T. and Lamming. R.C. (forthcoming). A Conceptual Model for Researching the Creation and Operation of Supply Networks. Accepted for publication in the British Journal of Management, June 2003.

of a business relationship is that co-operation co-exists along with conflict (Håkansson and Snehota, 1995). The ability of network partners to resolve conflicts is therefore important.

There are various mechanisms that can be used to deal with differences between actors such as steering committees, sign-off and approval procedures, informal mutual adjustments and plans and controls. It has also been argued that conflicts may be reduced through a reduction of diversity of views represented in the network; this may be achieved by selecting people with whom one has worked before or whom one trusts, and developing a common vision and frame of reference (Kumar, 1996).

\section{Motivation}

Motivation is the process by which the behaviour of network actors is energised and sustained. This activity appears to be allied to risk and benefit sharing in terms of incentive systems. The existence of various incentives systems has been shown to be an important co-ordination mechanism in consortia, franchises and other modes of inter-organisational co-operation (Grandori and Soda, 1995). Additionally, the sharing of property rights has been shown to be a key success factor in joint ventures and other 'equity alliances' as well as other forms of collaboration involving joint ownership of assets (Grandori and Soda, 1995; Killing, 1988).

In supply networks there is less evidence of research which has examined the issue of motivation, however, the practice whereby a customer acknowledges supplier achievement by granting awards, is clearly one way in which customers seek to motivate their suppliers. It may also involve the use of specific economic incentives, such as agreements to share future cost savings in component production costs. Other factors, such as mutual trust and commitment, are also important factors for initiating and sustaining inter-firms networking.

Table 1 summarises the main themes arising from the exploratory survey associated with each of the networking activities, and the main literature that underpins the importance of each activity. 
Harland, C.M., Zheng, J., Johnsen. T. and Lamming. R.C. (forthcoming). A Conceptual Model for Researching the Creation and Operation of Supply Networks. Accepted for publication in the British Journal of Management, June 2003.

Table 1. Literature Related to Nine Networking Activities

\begin{tabular}{|c|c|c|}
\hline $\begin{array}{l}\text { Networking } \\
\text { Activity }\end{array}$ & Themes & References \\
\hline Partner selection & $\begin{array}{l}\text { 1. Types of supply relationship } \\
\text { 2. Formation types } \\
\text { 3. History of prior engagement }\end{array}$ & $\begin{array}{l}\text { 1. Cousins (1992), Ellram } \\
\text { (1991) } \\
\text { 2. Doz et al (2000) } \\
\text { 3. Gulati (1998) }\end{array}$ \\
\hline $\begin{array}{l}\text { Resource } \\
\text { integration }\end{array}$ & $\begin{array}{l}\text { 1. Physical, site and human assets } \\
\text { specificity } \\
\text { 2. Human assets and site } \\
\text { specificity and supply network } \\
\text { performance } \\
\text { 3. Employee integration in } \\
\text { supplier networks } \\
\text { 4. Information systems integration: } \\
\text { VMI, continuous replenishment } \\
\text { 5. Buyer supplier adaptations }\end{array}$ & $\begin{array}{l}\text { 1. Williamson }(1979,1985) \\
\text { 2. Dyer (1996) } \\
\text { 3. Hines (1996) } \\
\text { 4. Scott-Morton (1991), } \\
\text { Lamming (1996) } \\
\text { 5. Brennan \& Turnbull (1995) }\end{array}$ \\
\hline $\begin{array}{l}\text { Information } \\
\text { processing }\end{array}$ & $\begin{array}{l}\text { 1. Information exchange dynamics } \\
\text { 2. Lean supply } \\
\text { 3. Supply chain } \\
\text { management/logistics } \\
\text { 4. IT }\end{array}$ & $\begin{array}{l}\text { 1. Julien and Lachance (1999) } \\
\text { 2. Lamming (1996), Womack et } \\
\text { al (1990) } \\
\text { 3. Christopher (1992), } \\
\text { Bowersox et al (1986) } \\
\text { 4. Scott-Morton (1991) }\end{array}$ \\
\hline $\begin{array}{l}\text { Knowledge } \\
\text { capture }\end{array}$ & $\begin{array}{l}\text { 1. } \text { Organisational learning } \\
\text { 2. Collective entrepreneurship } \\
\text { 3. Shared learning } \\
\text { 4. Exchange of tacit and } \\
\text { proprietary know how } \\
\text { 5. Learning in buyer-supplier } \\
\text { relationships, Kyoryokukai } \\
\text { 6. Learning networks } \\
\text { 7. Knowledge-sharing routines }\end{array}$ & $\begin{array}{ll}\text { 1. } & \text { Argyris and Schon (1978) } \\
\text { 2. Lundvall (1992) } \\
\text { 3. Garvin (1993) } \\
\text { 4. Helper (1990) } \\
\text { 5. Lamming (1996), Hines } \\
\text { (1996) } \\
\text { 6. Powell, Koput and } \\
\text { Smith-Doerr (1996) } \\
\text { 7. Dyer and Nobeoka (2000) }\end{array}$ \\
\hline $\begin{array}{l}\text { Social } \\
\text { co-ordination }\end{array}$ & $\begin{array}{l}\text { 1. Stable relationships based on } \\
\text { group norms, reputation and } \\
\text { peer control } \\
\text { 2. Trust, fine grained information } \\
\text { transfer and joint problem } \\
\text { solving }\end{array}$ & $\begin{array}{l}\text { 1. Grandori and Soda (1995), } \\
\text { Ouchi }(1979,1980) \\
\text { 2. Uzzi (1997) }\end{array}$ \\
\hline $\begin{array}{l}\text { Risk and benefit } \\
\text { sharing }\end{array}$ & $\begin{array}{l}\text { 1. Lean supply and cost } \\
\text { transparency } \\
\text { 2. Incentive systems } \\
\text { 3. Trust } \\
\text { 4. Benefit sharing and allowances } \\
\text { 5. Risk, responsibilities and } \\
\text { rewards }\end{array}$ & $\begin{array}{l}\text { 1. Lamming (1993), Womack et } \\
\text { al (1990) } \\
\text { 2. Grandori and Soda (1995) } \\
\text { 3. Ring and Van de Ven (1992), } \\
\text { Sako (1992) } \\
\text { 4. Stuart and McCutcheon } \\
\text { (1996) } \\
\text { 5. Hall (1999) }\end{array}$ \\
\hline
\end{tabular}




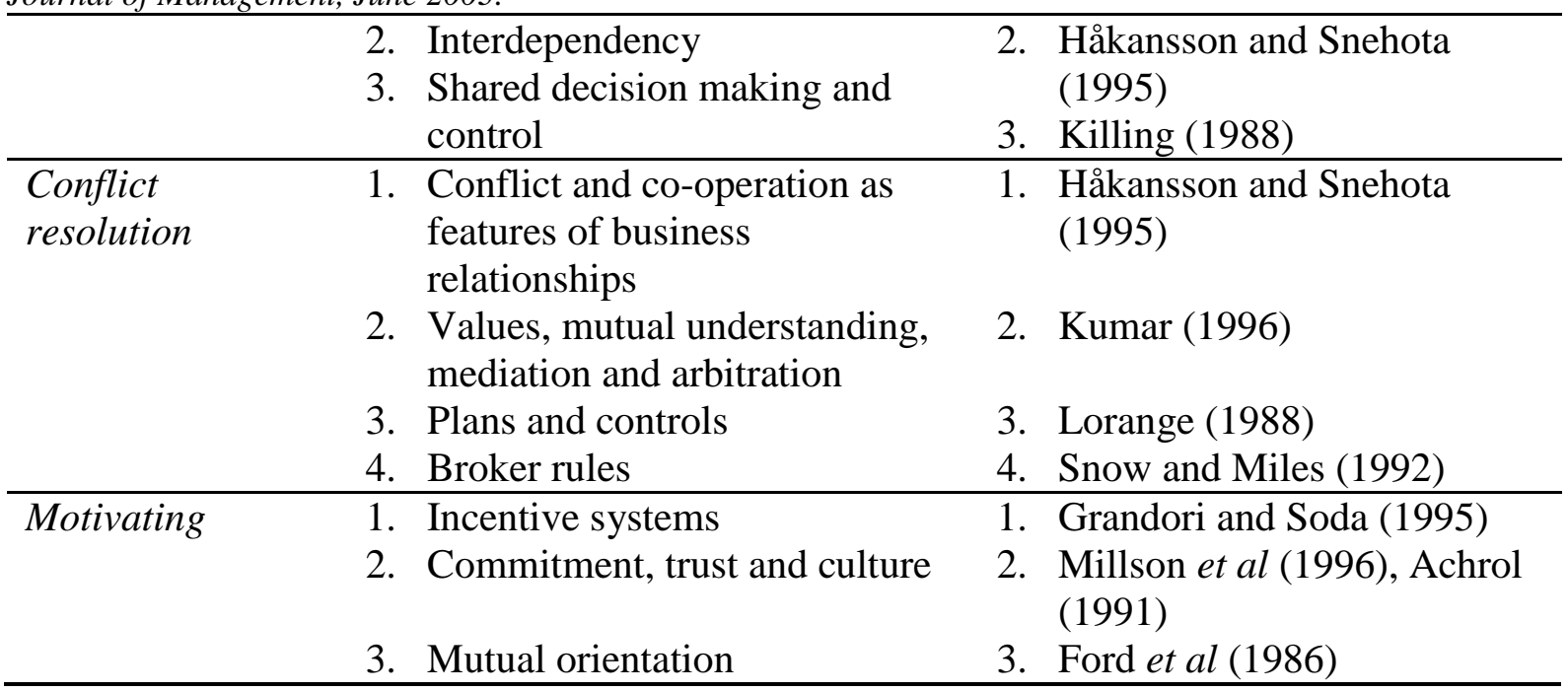

In the next section we review the literature relating to contextual variables highlighted in the exploratory survey.

\section{SUPPLY NETWORK CONTEXT}

The potential significance for network context to impact on behaviour in networks has been identified (Craven et al, 1996; Ebers and Grandori 1997; Snow and Miles, 1992). Each of the contextual variables highlighted in the exploratory survey are further investigated here.

\section{Market environment}

Cravens et al. (1996) distinguished between four types of network: 'flexible', 'hollow', virtual', and 'value-added', according to the dimensions of volatility of environmental change and the type of inter-organisational relationship involved (collaborative or transactional). For each of the four types of network they identified likely variations in market structure, technological complexity, core competency of the co-ordinating organisation, and the network members' core competences. The link between the environment and marketing channels, i.e. the downstream part of a supply network, has also been examined in channel management (Achrol et al, 1983; Achrol and Stern, 1988; Dwyer and Welsh, 1985). In an analysis of the relationships between a set of environment factors and marketing channels Achrol et al (1983) found that environment diversity among consumers, competitor and customer dynamism, market concentration, and market capacity were the most significant factors influencing decision making patterns. This is consistent with our findings related to the link between environment and supply networks (Zheng et al, 1997 and Johnsen et al, 1998), which suggest that the market environment may significantly influence the nature of supply networks.

\section{Product / process}

The nature of the product being supplied, the product structure, and the manufacturing process, are also key variables that may influence networking processes. For example, Fisher (1997) argued that the management of the supply chain for an innovative product should be different from that of a functional product due to differences in demand patterns. De Toni and Nassimbeni (1995) found the product structure and the nature of the operational interdependence between buyer and supplier influence the networking process in terms of the pipeline configuration and degree of centralised management of the pipeline. Elsewhere we have argued that the characteristics of a product supply network, in terms of the degree of product uniqueness and innovativeness, appear to 
Harland, C.M., Zheng, J., Johnsen. T. and Lamming. R.C. (forthcoming). A Conceptual Model for Researching the Creation and Operation of Supply Networks. Accepted for publication in the British Journal of Management, June 2003.

influence the extent of sharing of information and knowledge; supply networks of unique products generally exchanged less information and knowledge of a sensitive and strategic nature (Lamming et al, 2000).

\section{Supply network structure}

The structure of supply networks may influence networking processes; Dyer and Nobeoka (2000) highlighted that different network structures may be associated with different types of knowledge shared between parties; Nassimbeni (1998) associated different types of coordination in networks with different network structures. Complex products tend to incorporate a large number of components and hence the upstream part of supply networks are often equally large and complex; the complexity of processing information throughout the network implied a greater need for information technology in these complex product supply networks (Lamming et al, 2000). Harland (1998a) used cluster analysis to identify relationships between supply network structures and the propensity to use various forms of information technologies.

\section{Supply network strategy}

The supply network strategy of focal firms may influence how, and to what extent, networking is conducted. Harland (1998b) provided a supply strategy formulation process that connected strategy with supply network structure and infrastructure variables. Lamming (1996) discussed how manufacturers often seek to influence and manage their suppliers by the use of two strategies:- cascade and intervention. He identified several pitfalls in both of those strategies and the use of networking activities in supply networks; it has recently been exemplified how the use of networking activities in supply development can be managed within a large section of supply networks through the use of four different strategies:- cascade, intervention, vertical two-way, and network development (Lamming et al, 2000).

These contextual variables are summarised in Table 2 that relates the main themes with literature references.

Table 2. Literature related to network contextual variables

\begin{tabular}{|c|c|c|}
\hline Contextual Variables & Themes & References \\
\hline Market environment & $\begin{array}{l}\text { Volatility of environmental } \\
\text { change and the type of } \\
\text { inter-organisational } \\
\text { relationship } \\
\text { - Environment diversity and } \\
\text { decision making pattern } \\
\text { - Environmental } \\
\text { interdependence and type of } \\
\text { formation process }\end{array}$ & $\begin{array}{l}\text { Cravens et al (1996), Achrol et al } \\
\text { (1983), Zheng et al (1997), } \\
\text { Johnsen et al (1998), } \\
\text { Doz et al, }(2000)\end{array}$ \\
\hline
\end{tabular}

\begin{tabular}{llll}
\hline $\begin{array}{l}\text { Nature of product and } \\
\text { manufacturing } \\
\text { process }\end{array}$ & $\bullet \begin{array}{l}\text { Functional versus } \\
\text { innovative products and } \\
\text { supply chain focus }\end{array}$ & $\begin{array}{l}\text { Fisher (1997), Lamming et al } \\
\text { (2000), De Toni and Nassimbeni }\end{array}$ \\
& $\begin{array}{l}\text { Product innovativeness and } \\
\text { product uniqueness and }\end{array}$ & \\
& $\begin{array}{l}\text { information sharing } \\
\text { - }\end{array}$ & \\
& Product structure, \\
& operational interdependence \\
\hline
\end{tabular}


Harland, C.M., Zheng, J., Johnsen. T. and Lamming. R.C. (forthcoming). A Conceptual Model for Researching the Creation and Operation of Supply Networks. Accepted for publication in the British Journal of Management, June 2003.

\begin{tabular}{|c|c|c|}
\hline & and pipeline configuration & \\
\hline Network structure & 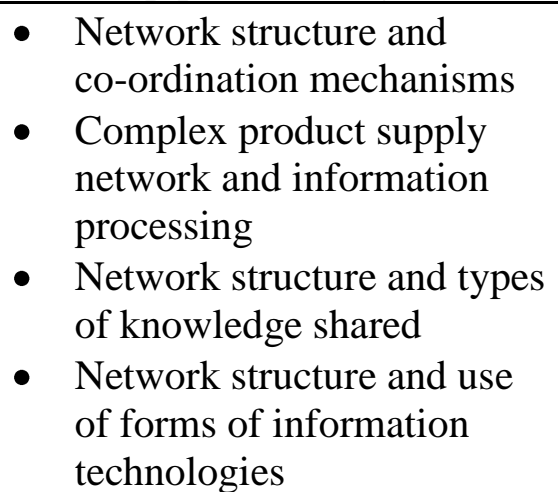 & $\begin{array}{l}\text { Nassimbeni (1998), Lamming et } \\
\text { al (2000), Dyer and Nobeoka } \\
\text { (2000), Harland (1998a) }\end{array}$ \\
\hline $\begin{array}{l}\text { Focal firm network } \\
\text { strategy }\end{array}$ & $\begin{array}{l}\text { Cascade, intervention, } \\
\text { vertical two-way, and } \\
\text { network development } \\
\text { - Supply strategy formulation }\end{array}$ & $\begin{array}{l}\text { Lamming (1996), Lamming et al } \\
\text { (2000), Harland (1998b) }\end{array}$ \\
\hline
\end{tabular}

This grounding of the data groups back into literature led to the development of the conceptual model.

\section{DEVELOPMENT OF A CONCEPTUAL MODEL FOR ANALYSING SUPPLY NETWORKING ACTIVITIES}

The findings from the two-stage literature review and the exploratory survey of 16 supply networks were used to develop the initial conceptual framework giving rise to the conceptual model provided in Figure 3.

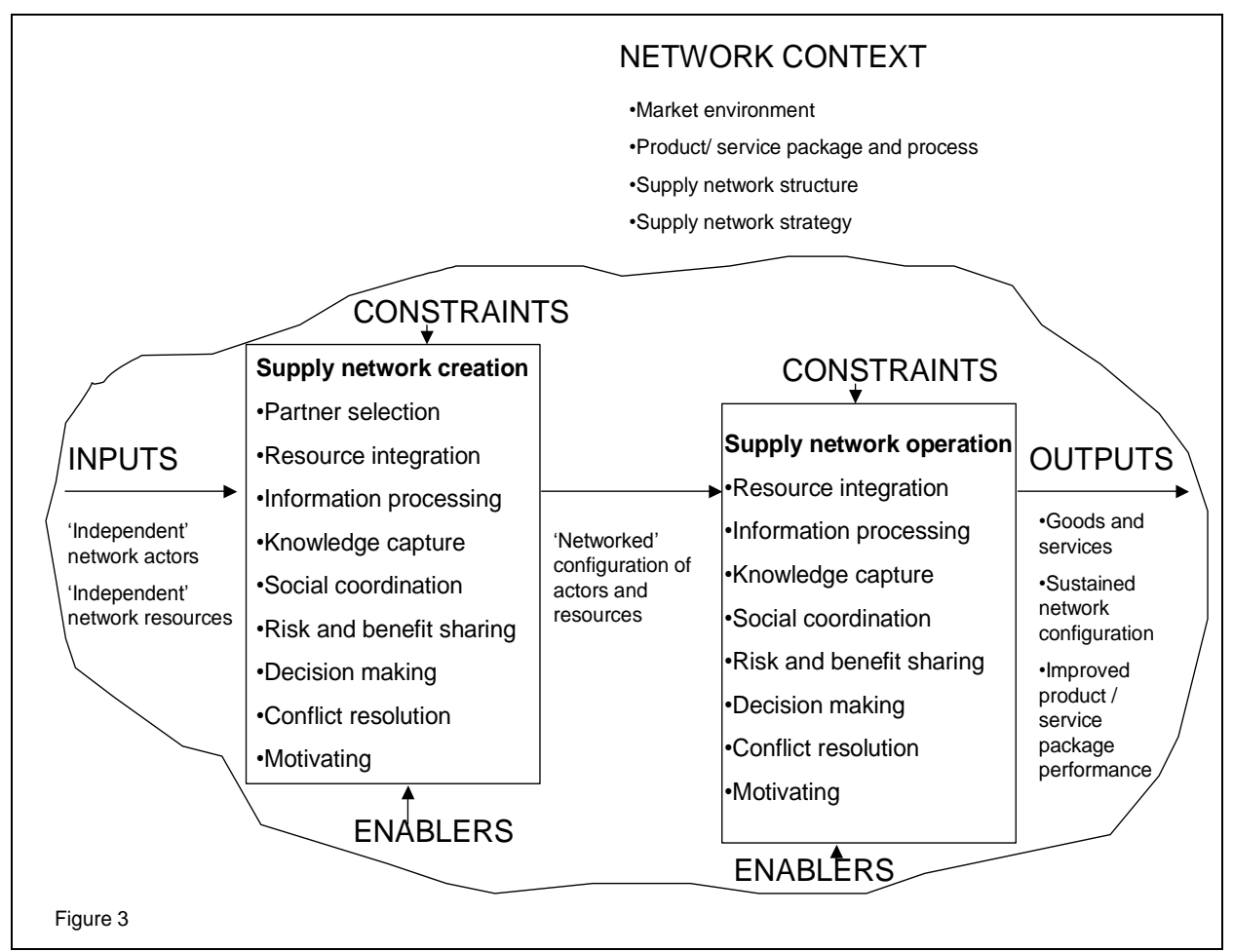

In this revised conceptual model the main categories of networking activity are included. As it was highlighted that partner selection was only appropriate for network creation / 
Harland, C.M., Zheng, J., Johnsen. T. and Lamming. R.C. (forthcoming). A Conceptual Model for Researching the Creation and Operation of Supply Networks. Accepted for publication in the British Journal of Management, June 2003.

recreation activities, the model shows two central boxes, one for the stage of creation, one for operation. Prior to network creation, the actors are not 'networked' relating to the specific product / service being examined and are therefore 'independent' of each other at that stage (though, as has been previously highlighted, they may be connected in other product / service supply networks, so are only 'independent' relative to the product / service supply network in focus). After 'creation' there is a configuration of supply network resources that can be 'operated'. Using the various networking activities, these resources are transformed to provide product/ service packages; the networking activities sustain the network configuration. Both network creation and operation occur in the context of the network contextual variables discussed previously.

'Enablers' and 'constraints' are broad terms for factors influencing the product / service supply network creation and operation activities. These factors may be resources, such as information technology systems; they may be other activities or processes, such as public relations activities. The lack of something might enable or constrain supply network creation or operation; for example, the lack of the supplier's relationships with a particular competitor may enable a buying company to provide confidential information more freely in the network; the lack of regulation in a particular country may enable a partner to be selected that has lower health and safety and environmental standards. The empirical research indicated that it was not appropriate to specify what enablers and constraints were as they were specific to each product / service supply network. Rather, they provided useful prompts to explore performance of the networking activities.

\section{APPLICATION OF THE CONCEPTUAL MODEL}

The conceptual model was used as the core model on which to base the empirical research in ProjectION of eight in-depth case studies of product / service supply networks. These case studies were in:

- Automotive manufacture

- Telecommunications equipment manufacture

- Domestic appliances manufacture

- Automotive components manufacture

- Pharmaceuticals manufacture

- Personal computer manufacture

- Confectionary manufacture

- Mobile phone manufacture

Each element of the conceptual model was explored within the case studies. This structure was used to assemble large tables of data allowing the researchers to look at each case and to look across cases under each element of the conceptual model. As the case studies were of supply networks, it was possible to look at each 'level' in the network (e.g. manufacturer, component manufacturer, material supplier), comparing networking activities across cases. An independent researcher was involved at this stage to verify findings from this method of pattern observation.

Patterns emerged connecting patterns of networking activities with patterns of supply network context; these findings were used to design a validating survey. The validating survey was a shorter, more structured survey of 58 focal firms chosen specifically to represent a range of different network contexts. Specific research questions were designed to examine the relationship between patterns of networking activities and patterns of network context. Combining the findings from this validating survey with those of the in-depth case studies, the exploratory survey and literature review resulted in 
Harland, C.M., Zheng, J., Johnsen. T. and Lamming. R.C. (forthcoming). A Conceptual Model for Researching the Creation and Operation of Supply Networks. Accepted for publication in the British Journal of Management, June 2003.

the formation of a supply network taxonomy (Harland et al, 2001); it is within this taxonomy that the empirical findings relating patterns of supply networking activity to patterns of product / service supply network context are presented.

\section{REFLECTIONS AND CONCLUSIONS}

The primary objective of this part of ProjectION was to select or develop a conceptual model that would enable investigation of networking activities in various network circumstances. The conceptual model presented in this paper is based on analysis of a wide range of literature, incorporating appropriate features of inter-organisation models from different management perspectives.

No one model appeared to be entirely appropriate to the research objectives of ProjectION. From examination of the limited empirical research in supply networks that had previously been conducted, it was not clear what such a model should comprise. The exploratory survey, therefore, flushed out main issues of concern to the survey participants and main observations of networking activities that were occurring and were important. Each networking activity had some prior research related to it, but there was no one overall conceptual model that combined all these. Also, the research relating to each activity was conducted from various management perspectives in various types of network; for this project we intended to investigate supply networks specifically.

The conceptual model formed the basis for analysis in the second and third empirical stages of ProjectION, namely in depth case study investigation of eight supply networks of different types and a broader validating survey of 58 supply networks in various sectors. It formed the core research instrument for the project. It enabled consistent cross case comparison across the in-depth case studies (see Johnsen et al, 2000) and various statistical analyses of the survey of 58 supply networks (see Zheng et al,1999). It formed the core structure to the design of the supply networks taxonomy that clustered different sets of networking activities appropriate to four main network contexts (see Harland et al, 2001).

The conceptual model informs research in supply networks in three key ways. First, investigating the set of networking activities within the model in supply networks provides a rich and structured understanding of what occurs in supply networks between network members. As these networking activities are grounded in a broad set of areas of literature, they generate findings that are multi-disciplinary and can be examined from a range of academic perspectives. We found this a useful way of engaging and leveraging capability of our multi-disciplinary research team. Each research team member, coming from their own particular perspective, found the application of these networking activities within the conceptual model, stretching; we had to rely heavily on other team members' expertise to use the model. This may make it difficult for single discipline teams or loan researchers to use the model as it is unlikely that they would have sufficient depth of knowledge to examine each activity.

The second key area that the conceptual model contributes to is the connection of networking activities within a supply network, with elements, and configurations of elements of, the supply network context. This enables researchers wishing to adopt a contingent approach to investigate and connect sets or patterns of networking activities as being more or less appropriate to particular context configurations. It may be possible to re-examine many of the supply network cases formed during the 1990s to see if they contain adequate data to explore the nature of networking activities within the particular 
Harland, C.M., Zheng, J., Johnsen. T. and Lamming. R.C. (forthcoming). A Conceptual Model for Researching the Creation and Operation of Supply Networks. Accepted for publication in the British Journal of Management, June 2003.

network context they are set. This might help us to reflect on a large number of issues, such as whether the approaches taken in high volume lower variety network contexts were appropriate only to those contexts, or whether there is evidence of certain networking activity sets being more universally appropriate.

The third key area of contribution lies in the provision of a conceptual model that, if applied in future empirical research in supply networks, will provide analytical consistency that will enable greater sharing and comparison of different research teams' work. However, we have only addressed the tip of the iceberg of empirical research of supply networks. There is a need for further testing of the conceptual model through empirical studies of networking contingencies and issues related to success of networking in a much larger number of network situations by different research teams taking different perspectives.

On reflection, there are limitations to this conceptual model. First, the categorisation of networking activities is, in itself, a false structure applied to messy interactions between parties in a network. For example, when applying the model to the in-depth cases we found difficulty in distinguishing between conflict resolution and decision making; it could be argued that merging these into one decision making category to include conflict resolution may be appropriate. However, keeping them as two distinct activities does provoke examination of conflict resolution specifically, so they have been left as separate categories. A second limitation relates to the model's lack of support to identify what enables and what constrains the activities. Whilst the lack of structured definition for these two categories of factors influencing networking activities gives the researcher freedom to explore a large range of resource or process issues, the vagueness of the terms can lead to identification of the first things that comes into interviewees' minds, rather than a comprehensive investigation of all possible factors. A further limitation is in the uncertainty of classifying what enables and what constrains; this limitation has been common to research based on the IDEF0 functional modelling approach (see, for example, Colquoun et al, 1989, and Godwin et al, 1989). The main limitation of the model is that it has only been applied by one research team in a limited number of product / service supply networks. Until other researchers attempt to use the model, its value will not have been rigorously tested. 
Harland, C.M., Zheng, J., Johnsen. T. and Lamming. R.C. (forthcoming). A Conceptual Model for Researching the Creation and Operation of Supply Networks. Accepted for publication in the British Journal of Management, June 2003.

\section{REFERENCES}

Achrol, R.S. (1991). 'Evolution of the Marketing Organisation: New Forms for Turbulent Environments', Journal of Marketing, 55, October, pp. 77-93.

Achrol, R.S. and Stern, L.W. (1988). 'Environmental Determinants of Decision making Uncertainty in Marketing Channels', Journal of Marketing Research, 25, February, pp. 36-50.

Achrol, R.S., Reve, T. and Stern, L.W. (1983). 'The Environment of Marketing Channel Dyads: A Framework for Comparative Analysis', Journal of Marketing, 47, pp. 55-67.

Alchian, A.A. and Demsetz, H. (1972). 'Production, Information Costs, and Economic Organisation', American Economic Association, 62 (5), pp. 777-795.

Anderson, J.C., Håkansson, H. and Johanson, J. (1994). 'Dyadic Business Relationships within a Business Network Context', Journal of Marketing, 58, October, pp. 1-15.

Argyris, C. and Schon, D. (1996). Organizational Learning II. Addison-Wesley, London.

Bowersox, D.J., Closs, D.J. and Helferich, O.K. (1986). Logistical Management ( $^{\text {rd }}$ edition). Macmillan Publishing.

Brass, D.J. and Buckhardt, M.E. (1992). 'Centrality and Power in Organisations'. In: N. Nohria, N. and Eccles, R.G. (eds.), Networks and Organisations, Harvard Business School Press, Boston, MA.

Brennan, R. and Turnbull, P.W. (1995). 'Adaptations in Buyer-Supplier Relationships, in Network Dynamics'. In: Nauru, P. and Turnbull, P.W. (ed.), International Marketing, pp. 26-41. Pergamon.

Campbell, A. and Wilson, D.T. (1996). 'Managed Networks: Creating Strategic Advantage', In: Dawn Iacobucci (ed.), Networks in Marketing, Sage Publications, pp.125-143.

Christopher, M.G. (1992). Logistics and Supply Chain Management. Pitman, London.

CIRIA/The Tavistock Institute (1996). Towards a Framework for Understanding Innovation, Learning and the Role of Inter-Company Networks in Construction. Steering Committee Meeting No 2.

Clark, K. and Fujimoto, T. (1991). Product development performance: strategy, organisation, and management in the world auto industry. Harvard Business School Press, Cambridge.

Coase, R.H. (1937). The Nature of the Firm, Economica, 5.

Colquoun G.J., Gamble J.D. and Baines R.W. (1989). 'Use of IDEF0 to Link Design and Manufacture in a CIM Environment', International Journal of Operations and Production Management, 9 (4), pp. 48-65.

Cousins, P.D. (2001). 'A Conceptual Model for Managing Long-term Inter-organisational Relationships', European Journal of Purchasing and Supply Management. 8 (2), pp. 71-82

Cousins, P.D. (1992). 'Purchasing a Professional Approach', Purchasing and Supply Management, Sept, pp. 20-23.

Cravens, D.W., Piercy, N.F. and Shipp, S.H. (1996). 'New Organisational Forms for Competing in Highly Dynamic Environments: The Network Paradigm', British Journal of Management, 7, pp. 203-218. 
Harland, C.M., Zheng, J., Johnsen. T. and Lamming. R.C. (forthcoming). A Conceptual Model for Researching the Creation and Operation of Supply Networks. Accepted for publication in the British Journal of Management, June 2003.

Doz, Y.L., Olk, P.M. and Ring, P.S. (2000). 'Formation Processes of R\&D Consortia: Which Path to Take? Where Does it Lead?'. Strategic Journal of Management, 21, pp. 239-266.

Dubois, A. (1994). Organising Industrial activities - An Analytical Framework, Department of Industrial Marketing, Chalmers University of Technology, Goteborg, Sweden.

Dwyer, F.R. and Welsh, M.A. (1985). 'Environmental Relationships of the Internal Political Economy of Marketing Channels', Journal of Marketing, 22, November, pp. 397-414.

Dyer, J. and Nobeoka, K. (2000). 'Creating and Managing a High Performance, Knowledge Sharing Network: The Toyota Case', Strategic Management Journal, 21, pp. 345-367.

Dyer, J.H. (1996). 'Specialised Supplier Networks as a Source of Competitive Advantage: Evidence from the Auto Industry', Strategic Management Journal, 17, pp. 271-291.

Easton, G. and Quayle, M. (1990). 'Single and Multiple Network Sourcing - Network Implications', Proceedings of 6th IMP Conference, Research and Developments in International Industrial Marketing and Purchasing, Milan. pp. 474-488.

Ebers, M. and Grandori, A. (1997). 'The Forms, Costs, and Development Dynamics of Inter-Organisational Networking', In: Ebers, M. (ed.), The Formation of Inter-Organisational Networks, Oxford University Press, pp. 265-286.

Ellram, L. (1991). 'A Managerial Guideline for the Development and Implementation of Purchasing Partnerships', International Journal of Purchasing and Materials Management, Summer, pp. 9-16.

Farmer, D.H. \& Ploos von Amstel, R. (1991). Effective Pipeline Management, Gower, UK.

Fisher, M.L. (1997). 'What is the right supply chain for your product?', Harvard Business Review, March-April, pp. 105-116.

Ford, I.D., Håkansson, H. and Johanson, J. (1986). 'How Do Companies Interact?' Industrial Marketing and Purchasing, 1, (1), pp. 26-41.

Forrester, J.W. (1961). Industrial Dynamics. MIT Press, Boston.

Fruin, M. (1992). The Japanese Enterprise System. Clarendon Press, Oxford.

Garvin, D. (1993). 'Building a Learning Organization', Harvard Business Review, 71 (4), pp. 78-91.

Godwin, A., Gleeson, J. and Gwilliam, D. (1989). 'An Assessment of the IDEF Notations as Descriptive Tools', Information Systems, 14 (1), January, pp. 13-28.

Grandori, A. (1997). 'An organisational Assessment of Interfirm Coordination Modes', Organisation Studies, 18 (6), pp. 897-925.

Grandori, A and Soda, G. (1995). 'Inter-firm Networks: Antecedents, Mechanisms and Forms', Organisation Studies, 16 (2), pp. 183-214.

Granovetter, M.S. (1985). 'Economics Action and Social Structure: The Problem of Embeddedness', American Journal of Sociology, 91 (3), pp. 481-510. 
Harland, C.M., Zheng, J., Johnsen. T. and Lamming. R.C. (forthcoming). A Conceptual Model for Researching the Creation and Operation of Supply Networks. Accepted for publication in the British Journal of Management, June 2003.

Granovetter, M.S. (1973). 'The Strength of Weak Tie', American Journal of Sociology, 78, pp. 1360-1380.

Gulati, R. (1998). 'Alliances and Networks', Strategic Management Journal, 19, pp. 293-317

Håkansson, H. \& Snehota, I. (1995). Developing Relationships in Business Networks, International Thomson Business Press, London.

Håkansson, H. \& Snehota, I. (1989). 'No Business is an Island: The Network Concept of Business Strategy', Scandinavian Journal of Management, 5 (3), pp187-200.

Håkansson, H. (ed.) (1987). Industrial Technological Development: A Network Approach, Croom Helm, London

Håkansson, H. (1982). International Marketing and Purchasing of Industrial Goods: An Interaction Approach, Wiley, Chichester.

Hall, R. (1999). 'Rearranging Risks and Rewards in a Supply Chain', Journal of General Management, 24 (3), pp. 22-32.

Harland, C.M. and Knight, L.A. (2001). 'Supply Network Strategy: Role and Competence Requirements', International Journal of Production and Operations Management, 21 (4), April, pp. 476-490.

Harland, C.M., Lamming, R.C., Zheng, J. and Johnsen, T.E (2001). 'A Taxonomy of Supply Networks', Journal of Supply Chain Management, Fall, 37 (4), pp.20-27.

Harland ,C.M., Lamming, R.C. and Cousins, P.D. (1999). 'Developing the Concept of Supply Strategy', International Journal of Operations and Production Management, 19, pp. 650-673.

Harland, C.M. (1998a). 'Supply Network Strategy: Observations on Structure, Infrastructure and Operations Performance', Proceedings of $2^{\text {nd }}$ Worldwide Research Symposium on Purchasing and Supply Chain Management, 1-3 Apr, London, pp. 248-268.

Harland, C.M. (1998b). 'Supply Network Strategy: a Formulation Process', In: Capaldo, G., Esposito, E., lo. Storto, C. and Raffa, M. (eds.), "Supply Management”, Edizioni Scientifiche Italiane S.p.A, Napoli, pp. 99-117.

Hines, P. (1996). 'Network Sourcing', In: Lamming, R.C. and Cox, A. (eds.), A Strategic Procurement Management in the 1990s: Concepts and Cases, Boston, Earlsgate Press, UK.

Helper, S. (1990). 'An Exit-Voice Analysis of Supplier Relations', Working paper number 90-23, Boston University, presented at the $2^{\text {nd }}$ Annual International Conference on Socio-Economics, Washington, D.C., March 1990.

Houlihan, J. (1987). 'International Supply Chain Management', IJPD \& MM, 17 (2), pp. 51-66.

ICAM (1981). Architecture Part II Volume IV Function Modelling Manual (IDEF0) AFWAL-TR-81-4023, Wright-Patterson Air Force Base. OH. USA

Jarillo, J.C. (1993). 'Strategic Networks: Creating the Borderless Organisation', Butterworth Heinemann, Oxford.

Jarillo, J.C. and Stevenson, H.H. (1991). 'Co-operative Strategies: The Payoffs and the Pitfalls', Long Range Planning, 24 (1). 
Harland, C.M., Zheng, J., Johnsen. T. and Lamming. R.C. (forthcoming). A Conceptual Model for Researching the Creation and Operation of Supply Networks. Accepted for publication in the British Journal of Management, June 2003.

Jarillo, J.C. (1988). 'On Strategic Networks', Strategic Management Journal, 9, pp. $31-41$.

Johnsen, T.E., Wynstra, F., Zheng, J., Harland, C.M. and Lamming, R.C. (2000). 'Networking Activities in Supply Networks', Journal of Strategic Marketing, 8 (2).

Johnsen, T.E, Zheng, J., Harland, C.M. and Lamming, R.C. (1998). 'Initial Classification of Supply Networks', Proceedings of 7th International Annual IPSERA Conference, London, pp. 264-276.

Johnstone, R. and Lawrence, P.R. (1988). 'Beyond Vertical Integration - The Rise of Value Adding Relationships', Harvard Business Review, July-August, pp. 94-101.

Jones, T.C. and Riley, D.W. (1985). 'Using Inventory for Competitive Advantage Through Supply Chain Management', International Journal of Physical Distribution and Materials Management, 15 (5), pp. 16-26.

Killing, J.P. (1988). 'Understanding Alliances: The Role of Take and Organisational Complexity', In Contract, F.J. and Lorange, P. (eds.), Co-operative Strategies in International Business, Lexington Books, pp. 55-67.

Kinch, N. (1992). 'Entering a Tightly Structured Network - Strategic Visions or Network Realities', In Forsgren, M. and Johanson, J. (eds.), Managing Networks in International Business, Philadelphia: Gordon \& Breach, pp. 194-214.

Kumar, N. (1996). 'The Power of Trust in Manufacturer-Retailer Relationships', Harvard Business Review, Nov-Dec, pp. 92-106.

Lamming, R.C., Johnsen, T.E., Harland, C.M. and Zheng, J. (2000). 'An Initial Classification of Supply Networks', International Journal of Operations and Production Management, 20 (6), pp. 675-692.

Lamming, R.C (1996). 'Squaring Lean Supply with Supply Chain Management', International Journal of Operations and Production Management, 10 (2), pp. 183-196.

Lamming, R.C., Cousins, P.D, Notman, D.M. (1996). 'Beyond Vendor Assessment: Relationship Assessment Programmes', European Journal of Purchasing and Supply Management, 2 (4), pp. 173-181.

Lamming, R.C. (1993). Beyond Partnership: Strategies for Innovation and Lean Supply. Prentice Hall, Hemel Hempstead, UK

Lorange, P (1988). 'Co-operative Strategies: Planning and Control Considerations, In: Hood, N. and Vahlne, J. (eds.), Strategies in Global Competition', Croom Helm, Routledge.

Lorenzoni, G. and Baden-Fuller, J. (1995). 'Creating a Strategic Centre to Manage a Web of Partners', California Management Review, 37 (3), Spring.

Lundvall, B.Å. (ed.) (1992). National Systems of Innovation: Towards a Theory of Innovation and Interactive Learning. Pinter Publishers, London.

Lundgren, A. (1995). Technological Innovation and Network Evolution Routledge, London

March, J.G. (1988). Decisions and Organisations. Basil Blackwell, Oxford.

Millson, M.R., Raj, S.P. and Wilemon, D. (1996). 'Strategic Partnering for Developing New Products’, Research Technology Management, May - June, pp. 41. 
Harland, C.M., Zheng, J., Johnsen. T. and Lamming. R.C. (forthcoming). A Conceptual Model for Researching the Creation and Operation of Supply Networks. Accepted for publication in the British Journal of Management, June 2003.

Nassimbeni, G (1998). 'Network Structures and Co-ordination Mechanisms - A Taxonomy', International Journal of Operations \& Production Management, 18 (6), pp.538-554.

New, S. and Burnes, B. (1998).'Developing Effective Customer-Supplier Relationship: More than One Way to Skin a Cat', International Journal of Quality and Reliability Management, 15 (4), pp. 377-388.

Nishiguchi, T. (1994). Strategic Industrial Sourcing, Oxford University Press, Oxford and New York.

Nohria, N. (1992). 'Is a Network Perspective a Useful way of Studying Organisations?' In N. Nohria and R. G. Eccles (eds.), Networks and Organisations: Structure, Form, and Action, Harvard Business School Press, Boston, MA, pp.1-22.

Nooteboom, B. (1993). 'Networks and Transactions: Do They Connect?' In: Groenewegen, J. (ed.), Dynamics of the Firm, Elsevier, Amsterdam.

Ouchi, W.G. (1980). 'Markets, Bureaucracies and Clans', Administrative Science Quarterly, 25, pp. 129-141.

Ouchi, W.G. (1979). 'A Conceptual Framework for Design of Organisational Control Mechanism', Management Science, 25, pp. 833-848.

Pierre-Andre, J. and Lachance, R. (1999). 'Networking: Willingness of Formal Network SME Members to Trade Information and a Descriptive Analysis of This Network', $44^{\text {th }}$ ICSB, World Conference, Naples, Italy.

Porter, M.E. (1987). 'Managing Value: From Competitive Advantage to Corporate Strategy', Harvard Business Review, May-June.

Porter, M.E. (1985). Competitive Advantage: Creating and Sustaining Superior Performance, Free Press.

Porter, M.E. (1980). Competitive Strategy. The Free Press, New York.

Powell WW, Kogut, K.W., Smith-Doerr, L (1996). 'Inter-organisational Collaboration and the Locus of Innovation: Networks of Learning in Biotechnology', Administrative Science Quarterly, 41.

Ring, P.S. and Van de Ven, A.H. (1992). 'Structuring Co-operative Relationships Between Organisations', Strategic Management Journal, 13, pp. 483-498.

Sabel, C., Herrigel, G., Kazis, R. and Deeg, R. (1987). 'How to Keep Mature Industries Innovative', Technology Review, 90 (3), pp. 26-35.

Sako, M. (1992). Prices, Quality and Trust: Inter-firm Relations in Britain and Japan. Cambridge University Press, Cambridge.

Saxenian, A. (1991). 'The Origins and Dynamics of Production Networks in Silicon Valley'. Research Policy, 20.

Scott-Morton, M.S. (ed.) (1991). The Corporation of the 1990s: Information Technology and Organisational Transformation, Oxford University Press, New York, NY.

Slack, N., Chambers, S., Harland, C.M., Harrison, A. and Johnston, R. (1998). 'Operations Management', 2nd Edition, Pitman, London.

Snow, C.C. and Miles R.E. and Coleman, Jr. (1992). 'Managing $21^{\text {st }}$ Century Network Organisations', Organisational Dynamics, Winter, pp. 5-20. 
Harland, C.M., Zheng, J., Johnsen. T. and Lamming. R.C. (forthcoming). A Conceptual Model for Researching the Creation and Operation of Supply Networks. Accepted for publication in the British Journal of Management, June 2003.

Stevens, G.C. (1989). 'Integrating the Supply Chain', International Journal of Physical Distribution and Materials Management, 19 (8), pp. 3-8.

Stuart, F.I. and McCutcheon, D. (1996). 'Sustaining Strategic Supplier Alliances', International Journal of Operation and Production Management, 16 (10), pp. 5-22.

de Toni, A. and Nassimbeni, G. (1995). 'Supply Networks: Genesis, Stability and Logistics Implications. A Comparative Analysis of Two Districts', Omega. International Journal of Management Science, 23 (4), pp. 403-418.

Tse, K.K. (1985). Marks \& Spencer: Anatomy of Britain's Most Efficiently Managed Company, Pergamon Press, Oxford.

Uzzi, B. (1997). 'Social Structure and Competition in Interfirm Networks: The Paradox of Embeddedness', Administrative Science Quarterly, 42, pp. 35-67.

Van de Ven, A.H., Emmit, D.C. and Koenig, R. (1975). 'Frameworks for Inter-Organisational Analysis', In: Negandhi, A. R. (ed.), Inter-Organisational Theory, Kent OH, Kent State University Press.

Williamson, O.E. (1985). The Economic Institutions of Capitalism, Free Press, New York.

Williamson, O.E. (1979). 'Transaction cost economics: The governance of contractual relations', Journal of Law and Economics, 22, pp. 233-261.

Williamson, O.E. (1975). Markets and Hierarchies. New York, Free Press.

Womack, J.P., Jones, D.T. and Roos, D. (1990). The Machine That Changed the World, Macmillan International.

Zheng, J., Harland, C.M., Johnsen, T.E. and Lamming, R.C. (2001). 'A Taxonomy of Supply Networks', Proc. Of $10^{\text {th }}$ International IPSERA Conference, Sweden, Apr. 8-11, Jonkoeping, Sweden.

Zheng, J, Harland C.M., Johnsen, T.E. and Lamming, R.C. (1999). 'Methodological Issues in Inter-Organisational Supply Networks Research', In Bartezzaghi E, Filippini R, Spina G and Vinelli A (eds.), Managing Operations Networks, Servici Grafici Editoriali, Padova, pp. 111-121.

Zheng, J., Harland, C.M, Johnsen, T.E., \& Lamming, R.C. (1997). 'Features of Supply Networks', presented at the British Academy of Management Annual Conference, London, 8-10 September. 